\title{
Anthropometric and Body Composition Differences Among Genotype Controlled Indigenous Adult Kiwcha Natives Living at Low (230 M) and High Altitude $(3,800 \mathrm{M})$ in Ecuador
}

\section{Esteban Ortiz-Prado ( $\sim$ e.ortizprado@gmail.com )}

Universidad de Las Américas https://orcid.org/0000-0002-1895-7498

\section{Gonzalo Mendieta}

Universidad de Las Américas: Universidad de Las Americas

\section{Katherine Simbaña-Rivera}

Universidad de Las Américas: Universidad de Las Americas

\section{Lenin Gomez-Barreno}

Universidad de Las Américas: Universidad de Las Americas

\section{Samanta Landazuri}

Universidad de Las Américas: Universidad de Las Americas

\section{Eduardo Vasconez}

Universidad de Las Américas: Universidad de Las Americas

\section{Manuel Calvopiña}

Universidad de Las Américas: Universidad de Las Americas

\section{Ginés Viscor}

Universitat de Barcelona - Campus Mundet

\section{Research}

Keywords: Anthropometric, High Altitude, Natives, Adaptation, Hypoxia, Weight, Height, BMI

Posted Date: September 27th, 2021

DOl: https://doi.org/10.21203/rs.3.rs-917384/v1

License: (1) This work is licensed under a Creative Commons Attribution 4.0 International License. Read Full License

Version of Record: A version of this preprint was published at Journal of Physiological Anthropology on March 10th, 2022. See the published version at https://doi.org/10.1186/s40101-022-00280-6. 


\section{Abstract}

Background: Anthropometric measures have been classically used to understand the impact of environmental factors on the living conditions of individuals and populations. Most reference studies on development and growth in which anthropometric measures were used were carried out in populations that are located at sea level but there are few studies carried out in high altitude populations

Objective: The objective of this study is to evaluate anthropometric and body composition in autochthonous Kiwchas permanently living at low and high-altitude.

Methodology: A cross-sectional study of anthropometric and body composition between genetically matched lowland Kiwchas from Limoncocha $(230 \mathrm{~m}$ ) at Amazonian basin and high-altitude Kiwchas from Oyacachi $(3,180 \mathrm{~m})$ in Andean highlands. Student's t-test was used to analyze differences between continue variables and Chi square test was performed to check the association or independence of categorical variables. Fisher 's exact test or Spearman test were used when the variable had evident asymmetries with histograms prior to the selection of the test.

Results: Our study shows that low altitude women are shorter and heavier, but these differences are not statistically significant ( $p$ value 0.333 ) on the other hand high altitude men are shorter than their counterparts who live at low altitude with a p value 0.019 . In relation to body muscle $\%$, women at high altitudes have less body muscle \% (-24.8\%) while men at high altitudes have significantly more muscle body mass \% (+ 13.5\%) than their lowland counterpart. Body fat \% is lower among low altitude women $(-15.5 \%)$ and no differences were found among men.

Conclusions: This is the first study to be performed in two genotyped controlled matching populations located at different altitudes. The anthropometric differences vary according to sex, demonstrating that high altitude population are in general lighter and shorter than their low altitude controls. Men at high altitude have more muscled bodies than their lowland counterpart but their body age was older than their real age.

\section{Introduction}

Body composition and size, weight, and height as well as body mass index (BMI) are shaped by genetic, environmental, and sociodemographic circumstances. These features can be subtle or marked, and depending on time; they can be temporal or perennial $(1,2)$. These changes depend on genetic traits that have been passing from generation to generation and can modify how humans evolve, resulting in different phenotypes for different populations (3-8).

One of the factors associated with evolutionary changes has been the elevation at which a population resides(9). High altitude exposure is associated with a reduced oxygen availability, utilization or consumption that has several physiological and pathological implications among acclimatized and adapted humans(10).

These adaptations often vary from place to place and more importantly in how much time the exposure has had to push genetic, anatomical, morphological, or physiological changes $(9,11)$. In this sense, long-term 
high altitude exposure has triggered several adaptation mechanisms and anthropometric differences that vary from region to region $(9,12-14)$.

Most reports on the adaptive mechanisms that humans have undergone in relation to the environmental conditions at which their ancestors were exposed have been studied in populations located at sea level, nevertheless, high-altitude triggered changes are significant $(15,16)$.

Some adaptive changes described among high altitude populations rely on how much time has passed(17). For instance, inhabitants from the Himalayas mountainous regions have adapted differently than Andean high altitude dwellers $(18,19)$. Greater and wider chest as well as smaller bodies are some of the features of the Andean high altitude natives, while thinner and taller bodies have been described among Himalayan Sherpas $(9,17-19)$.

Some of these morphological and adaptative differences are evident at birth, while others can be observed al older ages $(20,21)$. A study carried out by Bolaños et al. in Peru within populations located at 3,000 meters above sea level and 2,320 meters above sea level reported that physical growth at high altitudes, it is affected by a small $(1-4 \mathrm{~cm})$ delay in linear growth and skeletal maturation (22). It was also observed that the chest circumference among high altitude children $(4,150 \mathrm{~m})$ is $12-15 \%$ greater compared to American and Peruvian children that were born at sea level (22).

Most of those anthropometric and physiological differences between the populations living at high altitudes in different parts of the world are based in the wide differences in the time and generations passed from the initial colonization of these high altitude ecological niches $(23,24)$. So, genetical architecture of altitude adapted human populations could play an important role in their anatomical and morphological development as a mean to better survive at high altitude. As noted, evolutionary differences between various populations have been compared on some occasions, however, the comparisons are usually between distinct populations residing in different locations.

The main goal of this study was to compare some anthropometrical variables and body composition parameters in two genetically homogeneous populations of Kiwcha ascent living at low and high altitudes from several generations.

\section{Methodology}

\section{Study design}

A cross-sectional analysis of the differences in anthropometry parameters and body composition was carried out in two populations of kiwchas, natives from Ecuador.

\section{Setting}

This study was carried out in Ecuador in two geographically different areas, the Andes and the Amazon Basin. The research work began in January 2017 and concluded in August 2019. 
Ecuador with an area of more than $283,000 \mathrm{Km} 2$ is the smallest country in the Andean mountainous region in South America. The country is divided into 4 geographical regions, the coast, the highlands, the Amazon region, and the Galapagos Islands. The political division encloses 24 provinces, 10 from the highlands, 7 from the coast, 6 from the Amazon region and 1 from the insular region of Galapagos. Every province has several political divisions called cantons and they are comparable to cities elsewhere. The country has 141 cantons at low altitude, 28 at moderate altitude, 41 at high altitude and 11 at very high altitude. Limoncocha is located at low altitude while Oyacachi is located at very high altitude (Figure 1).

\section{Participants}

All the participants who voluntarily agreed are members of the Kiwcha indigenous group from Ecuador. The high-altitude group came from Oyacachi, a small Kiwcha community located at $3,800 \mathrm{~m}$ of elevation while the low-altitude group came from Limoncocha, located at $230 \mathrm{~m}$ of elevation.

\section{Inclusion criteria}

The study will be carried out in healthy volunteers of both sexes without any type of comorbidity or chronic disease, between the ages of 18 and 85 who were born and currently residing in Oyacachi (high-altitude group) and in Limoncocha (low altitude group).

\section{Exclusion criteria}

Volunteers who are under 18 years of age, who were born in another community and those who does not habitually reside in the parishes were excluded from the study. Those volunteers who did not complete the anthropometric measurements were excluded from the analysis.

\section{Variables and outcomes}

Sociodemographic variables, such as age, sex, marital status, and place of residence were recorded. We included the following anthropometric measurements Weight $(\mathrm{Kg})$, Height $(\mathrm{cm})$, Body Mass Index (BMI), Shoulder height $(\mathrm{cm})$, Hip height $(\mathrm{cm})$, Buttock height $(\mathrm{cm})$, Lateral arm length $(\mathrm{cm})$, Shoulder height $(\mathrm{cm})$ median (IQR), Biacromial Shoulder Width $(\mathrm{cm})$, Biiliac width $(\mathrm{cm})$, Arm length $(\mathrm{cm})$, Chest circumference $(\mathrm{cm})$, Waist circumference $(\mathrm{cm})$, Head circumference $(\mathrm{cm})$,Body composition grease $(\%)$, Body composition Muscle (\%),Corporal Age (years), Real Age (years).

The main outcome is to determine the possible anthropometric differences between genotypematched Kiwcha indigenous people who live at high altitudes versus their counterparts who live at low altitudes

\section{Data sources}

Individual-level socio-demographic information, place of residence and past medical history was obtained insitu in both communities. A complete physical examination including body weight, height, and $\mathrm{t}$ anthropometric variables recording was performed. 


\section{Study size and sample size calculation:}

In terms of the number of patients required to achieve significance the sample size $(n)$ and margin of error $(E)$ were given by the following formula:

$\begin{aligned} x & =Z(C / 100)^{2} r(100-r) \\ n & =N x /\left((N-1) E^{2}+x\right) \\ E & =\operatorname{Sqrt}[(N-n) x / n(N-1)]\end{aligned}$

Where $N$ is the population size ( $\mathrm{n}=570$ in Oyacachi and $\mathrm{n}=890$ in Limoncocha), $(r)$ is the fraction of expected responses $(50 \%)$, and $Z(c / 100)$ is the critical value for the confidence level $(c)$. The total number of medical and physical evaluations required to achieve statistical significance was 82 for the high-altitude group and 96 for the low-altitude control group. Through a non-probability convenience-based sampling technique 117 patients were included in Limoncocha and 95 for Oyacachi.

\section{DNA extraction and analysis of ancestry ratios}

To compare the ancestry of the two populations, a subsample of 47 unrelated individuals (30 Oyacachi vs 17 Limoncocha) was selected. We looked for a subsample among all the individuals to identify those subjects who did not have any first order degree of consanguinity, condition that is based on our laboratory protocol for ancestry analysis. DNA extraction was performed from FTA cards (GE Healthcare) by the Chelex method, then the extracts were diluted to a concentration of $5 \mathrm{ng} / \mathrm{ul}$ using the NanoDrop 2000 UV-Vis spectrophotometer (Thermo Scientific, Waltham, MA)(25). 46-plex autosomal ancestry informative deletioninsertion markers (46-plex AIMs-InDel) were amplified. Fluorescent amplicons were sized by capillary electrophoresis in Pop-7 polymer using a genetic analyzer ABI 3130 (Applied Biosystems, Austin, TX). Alleles were named by the software Genemapper V 3.1 (Life Technologies, Carlsbad, CA) following nomenclature described by Pereira et al, 2012(26). Taking into account tri-hybrid historic mixture in Ecuador(27-29), Inference of ancestry proportions were obtained considering the admixture model with $\mathrm{K}=3$ (based in Runs consisted of 100,000 burnin steps, followed by 100,000 Markov Chain Monte Carlo (MCMC) using STRUCTURE V2.3.4 software(30).

All runs were made without any prior information on the origin of samples and only considered the genetic background for the ancestral continental populations based on reference samples: European, EUR $(n=158)$, African, AFR $(n=105)$, and Native American, NAM $(n=64)$. Reference genotypes were extracted from the diversity panel of the Human Genome Diversity Project-Center d'Etude du Polymorphisme Humain (HGDPCEPH). The populations selected as comparative groups for Africa were: Angola $(n=1)$, Botswana $(n=4)$, Central African Republic $(n=23)$, Congo $(n=13)$, Kenya $(n=11)$, Lesotho $(n=1)$, Namibia $(n=6)$, Nigeria $(n$ $=22)$, Senegal $(n=22)$ and, South Africa $(n=2)$, for South America: Brazil $(n=22)$, Colombia $(n=7)$, and Mexico $(n=35)$, and for Europe were: France $(n=52)$, Italy $(n=49)$, Orkney Islands $(n=15)$ and Russia $(n=$ 42). 


\section{Data analysis}

Descriptive statistics were used to analyze and visualize differences between the two populations. Student's t-test was used to analyze differences between continue variables and Chi square test was performed to check the association or independence of categorical variables. When the expected values were less than 5 in any of the categories, Fisher's exact test or Spearman's test were used when the variable had evident asymmetries with histograms prior to the selection of the test. The strength of association between categorical variables was performed using the $\mathrm{V}$-Cramer test.

All statistical analysis accepted significance for a p-value $<0.05$. Calculations were completed using the IBM Corp. Released 2014. IBM SPSS Statistics for Windows, Version 24.0. Armonk, NY: and R Core Team software 2018 version 3.5.1. Cartography was generated using QGIS Development Team 2.8 and all the references were managed using the open source software Zotero 5.0.85

\section{Ethical consideration}

A full ethical approval was obtained (\#MED.EOP.17.01) thought out the Universidad de las Americas bioethics committee (CEISH). All patients voluntarily signed an informed consent. For people who could not read or write, an official community translator and a family member capable of understanding what was described in the document were used to explain the entire context of the project and ensure that there were no doubts about it. To protect the identity and autonomy of patients, all personal information was coded to ensure anonymity

\section{Results}

A total of 212 subjects were recruited successfully in both communities. $55 \%(n=117)$ were included from the Limoncocha low altitude group and $45 \%(n=95)$ from the Oyacachi high altitude group. In general, women represented $63 \%(n=134)$ from the entire cohort and men $37 \%(n=78)$.

\section{Age and sex differences}

Within our cohort, women from the low altitude group were on average 4 years older (41.0 [30.0-59.0]) than women from the high altitude group (36.0 [29.0-48.0]), nevertheless, this difference was not statistically significant (p: 0.121) (Table 1) Low altitude men were on average 5 years older (42.0 [30.0-52.0]) than men living at high altitudes (36.0 [25.0-57.0]), similarity to women, this difference was not significant ( $p$ value $0.420)$.

\section{Weight (Kg) and BMI}

In relation to weight, we found that women at high altitudes $(60.84 \mathrm{Kg} \pm 8.333 \mathrm{Kg})$ are on average $1.9 \mathrm{kilos}$ lighter than women at low altitudes $(62.75 \pm 14.44 \mathrm{Kg}$ ) but this difference was not statistically significant ( $p$ value 0.374$)$. Men living at high altitudes are $20.7 \%$ lighter than their counterpart at low altitudes ( $p$-value < 0.0001) (Table 1). 
In terms of overweight, women living at high altitudes have a higher proportion (51.8\%) of overweight subjects than those living at low altitudes (39.7\%); however, for men, this relationship is reversed, with those living at low altitudes having a higher proportion (55\%) of overweight subjects than those living at high altitude (41\%).

In terms of obesity, the low altitude group in both men and women has a higher proportion of obese subjects (16.4\%) than those subjects living at high altitudes (8.8\%), being these differences statistically significant (Table 1). In terms of extreme obesity, we only found 10 women and 6 men having extreme obesity (BMI > 40 ), belonging all of these to the low altitude group (Table 1 ).

Table 1

Sociodemographic, anthropometric and risk factors analysis from the low and high cohorts.

\begin{tabular}{|c|c|c|c|c|c|c|c|c|c|}
\hline & & \multicolumn{4}{|l|}{ Female } & \multicolumn{4}{|l|}{ Male } \\
\hline & & $\begin{array}{l}\text { Low } \\
\text { altitude }\end{array}$ & $\begin{array}{l}\text { High } \\
\text { altitude }\end{array}$ & $\begin{array}{l}\text { (\%) } \\
\text { Diff }\end{array}$ & Sig. & $\begin{array}{l}\text { Low } \\
\text { altitude }\end{array}$ & $\begin{array}{l}\text { High } \\
\text { altitude }\end{array}$ & $\begin{array}{l}\text { (\%) } \\
\text { Diff }\end{array}$ & Sig. \\
\hline \multicolumn{2}{|c|}{$\begin{array}{l}\text { Age (Years) - median } \\
\text { (IQR) }\end{array}$} & $\begin{array}{l}41.0 \\
(30.0- \\
59.0)\end{array}$ & $\begin{array}{l}36.0 \\
(29.0- \\
48.0)\end{array}$ & 13.0 & 0.121 & $\begin{array}{l}42.0 \\
(30.0- \\
52.0)\end{array}$ & $\begin{array}{l}36.0 \\
(25.0- \\
57.0)\end{array}$ & 15.4 & 0.420 \\
\hline \multirow[t]{3}{*}{$\begin{array}{l}\text { Age } \\
\text { categories }\end{array}$} & $\begin{array}{l}\text { Young } \\
\text { Adult }\end{array}$ & $\begin{array}{l}45 \\
(57.0)\end{array}$ & $\begin{array}{l}41 \\
(73.2)\end{array}$ & 9.3 & 0.086 & $\begin{array}{l}24 \\
(54.5)\end{array}$ & $\begin{array}{l}27 \\
(67.5)\end{array}$ & 11.7 & 0.475 \\
\hline & Adult & $\begin{array}{l}19 \\
(24.1)\end{array}$ & $\begin{array}{l}11 \\
(19.6)\end{array}$ & 53.3 & 0.086 & $\begin{array}{l}15 \\
(34.1)\end{array}$ & $\begin{array}{l}10 \\
(25.0)\end{array}$ & 40.0 & 0.475 \\
\hline & Elderly & $\begin{array}{l}15 \\
(19.0)\end{array}$ & $4(7.1)$ & 115.8 & 0.086 & $\begin{array}{l}5 \\
(11.4)\end{array}$ & $3(7.5)$ & 50.0 & 0.475 \\
\hline \multicolumn{2}{|c|}{ Weight $(\mathrm{Kg})$ - mean \pm SD } & $\begin{array}{l}62.75 \\
\pm 14.44\end{array}$ & $\begin{array}{l}60.84 \\
\pm 8.33\end{array}$ & 3.1 & 0.374 & $\begin{array}{l}74.26 \\
\pm 10.83\end{array}$ & $\begin{array}{l}60.34 \\
\pm 8.71\end{array}$ & 20.7 & 0.000 \\
\hline \multicolumn{2}{|c|}{ Height $(\mathrm{cm})$ - mean \pm SD } & $\begin{array}{l}149.22 \\
\pm 7.01\end{array}$ & $\begin{array}{l}152.61 \\
\pm 8.62\end{array}$ & 2.3 & 0.333 & $\begin{array}{l}159.90 \\
\pm 6.39\end{array}$ & $\begin{array}{l}155.51 \\
\pm 9.93\end{array}$ & 2.8 & 0.019 \\
\hline \multicolumn{2}{|c|}{$\mathrm{BMI}-$ mean $\pm \mathrm{SD}$} & $\begin{array}{l}27.90 \\
\pm 5.10\end{array}$ & $\begin{array}{l}26.10 \\
\pm 3.10\end{array}$ & 6.7 & 0.022 & $\begin{array}{l}29.00 \\
\pm 4.20\end{array}$ & $\begin{array}{l}24.90 \\
\pm 2.90\end{array}$ & 15.2 & 0.000 \\
\hline \multirow[t]{5}{*}{$\begin{array}{l}\text { BMI } \\
\text { categories }\end{array}$} & $\begin{array}{l}\text { Under } \\
\text { Weight }\end{array}$ & $0(0.0)$ & $0(0.0)$ & 0.0 & 0.036 & $0(0.0)$ & $0(0.0)$ & 0.0 & 0.000 \\
\hline & Normal & $\begin{array}{l}25 \\
(32.1)\end{array}$ & $\begin{array}{l}20 \\
(35.7)\end{array}$ & 22.2 & 0.036 & $\begin{array}{l}5 \\
(12.5)\end{array}$ & $\begin{array}{l}21 \\
(53.8)\end{array}$ & 123.1 & 0.001 \\
\hline & Overweight & $\begin{array}{l}31 \\
(39.7)\end{array}$ & $\begin{array}{l}29 \\
(51.8)\end{array}$ & 6.7 & 0.036 & $\begin{array}{l}22 \\
(55.0)\end{array}$ & $\begin{array}{l}16 \\
(41.0)\end{array}$ & 31.6 & 0.002 \\
\hline & Obesity & $\begin{array}{l}12 \\
(15.4)\end{array}$ & $\begin{array}{l}7 \\
(12.5)\end{array}$ & 52.6 & 0.036 & $\begin{array}{l}7 \\
(17.5)\end{array}$ & $2(5.1)$ & 111.1 & 0.003 \\
\hline & $\begin{array}{l}\text { Extreme } \\
\text { Obesity }\end{array}$ & $\begin{array}{l}10 \\
(12.8)\end{array}$ & $0(0.0)$ & & 0.036 & $\begin{array}{l}6 \\
(15.0)\end{array}$ & $0(0.0)$ & & 0.004 \\
\hline
\end{tabular}




\section{Stature (cm)}

In terms of stature, women from the high altitude group are $3.3 \mathrm{~cm}$ taller $(152.6 \mathrm{~cm} \pm 8.62 \mathrm{~cm})$ than women from the low altitude group $(149.2 \mathrm{~cm} \pm 7.01 \mathrm{~cm})$, however this difference was not statistically significant $(p$ value 0.333). Among men, however, high altitude dwellers are $4.3 \mathrm{~cm}$ shorter $(155.5 \mathrm{~cm} \pm 9.93 \mathrm{~cm})$ than lowlanders $(159.9 \mathrm{~cm} \pm 6.39 \mathrm{~cm}$ ), being this difference statistically significant ( $p$ value 0.019$)$ (Fig. 2).

\section{Anthropometric characteristics}

Low altitude women are shorter $(-2.3 \%)$ and heavier $(+3.1 \%)$ than women living at high altitude (Table 1$)$. Shoulder height $(-0.3 \%)$, chest circumference $(-0.7 \%)$ and waist circumferences $(-9.1 \%)$ were also smaller in the low altitude group (Fig. 3).

\section{Head circumferences}

We found that head circumference is significantly smaller among low altitude women $(-3.6 \%)$ and those women living at high altitude. Head Circumference was also smaller for low altitude men (-2.7\%) (Table 2 and Fig. 3). 
Table 2

Anthropometric measurements among low and high altitude dwellers

\begin{tabular}{|c|c|c|c|c|c|c|c|c|}
\hline & \multicolumn{4}{|l|}{ Female } & \multicolumn{4}{|l|}{ Male } \\
\hline & $\begin{array}{l}\text { Low } \\
\text { altitude }\end{array}$ & $\begin{array}{l}\text { High } \\
\text { altitude }\end{array}$ & $\begin{array}{l}\text { (\%) } \\
\text { Diff }\end{array}$ & Sig. & $\begin{array}{l}\text { Low } \\
\text { altitude }\end{array}$ & $\begin{array}{l}\text { High } \\
\text { altitude }\end{array}$ & $\begin{array}{l}(\%) \\
\text { Diff }\end{array}$ & Sig. \\
\hline $\begin{array}{l}\text { Shoulder height } \\
(\mathrm{cm})\end{array}$ & $\begin{array}{l}126.7 \pm \\
6.8\end{array}$ & $\begin{array}{l}127.1 \pm \\
7.6\end{array}$ & 0.3 & 0.729 & $\begin{array}{l}136.5 \pm \\
6.8\end{array}$ & $\begin{array}{l}128.90 \pm \\
8.2\end{array}$ & 5.7 & 0.000 \\
\hline Hip height (cm) & $85.0 \pm 4.5$ & $84.1 \pm 5.6$ & 1.1 & 0.323 & $\begin{array}{l}89.0 \pm \\
4.0\end{array}$ & $83.2 \pm 6.1$ & 6.7 & 0.000 \\
\hline $\begin{array}{l}\text { Buttock height } \\
\text { (cm) }\end{array}$ & $66.6 \pm 3.7$ & $65.4 \pm 4.7$ & 1.8 & 0.095 & $\begin{array}{l}69.5 \pm \\
3.0\end{array}$ & $66.7 \pm 5.5$ & 4.1 & 0.011 \\
\hline $\begin{array}{l}\text { Lateral arm } \\
\text { length (cm) }\end{array}$ & $\begin{array}{l}153.0 \\
(148.0- \\
156.0)\end{array}$ & $\begin{array}{l}152.0 \\
(149.0- \\
160.0)\end{array}$ & 0.7 & 0.520 & $\begin{array}{l}165.0 \\
(158.0- \\
175.0)\end{array}$ & $\begin{array}{l}161.0 \\
(151.0- \\
167.0)\end{array}$ & 2.5 & 0.048 \\
\hline $\begin{array}{l}\text { Shoulder height } \\
(\mathrm{cm})^{\star}\end{array}$ & $\begin{array}{l}40.0 \\
(37.0- \\
41.0)\end{array}$ & $\begin{array}{l}41.0 \\
(39.0- \\
45.0)\end{array}$ & 2.5 & 0.002 & $\begin{array}{l}44.0 \\
(43.0- \\
46.0)\end{array}$ & $\begin{array}{l}42.0 \\
(40.0- \\
44.0)\end{array}$ & 4.7 & 0.004 \\
\hline $\begin{array}{l}\text { Biacromial } \\
\text { Shoulder Width } \\
(\mathrm{cm})\end{array}$ & $\begin{array}{l}52.0 \\
(49.0- \\
57.0)\end{array}$ & $\begin{array}{l}50.0 \\
(43.0- \\
53.5)\end{array}$ & 3.9 & 0.001 & $\begin{array}{l}52.0 \\
(47.0- \\
55.0)\end{array}$ & $\begin{array}{l}49.0 \\
(39.0- \\
52.0)\end{array}$ & 5.9 & 0.045 \\
\hline $\begin{array}{l}\text { bi-iliac width } \\
\text { (cm) }\end{array}$ & $50.0 \pm 8.0$ & $\begin{array}{l}49.00 \pm \\
5.0\end{array}$ & 2.0 & 0.641 & $\begin{array}{l}49.0 \pm \\
5.0\end{array}$ & $48.0 \pm 5.0$ & 2.1 & 0.477 \\
\hline Arm length (cm) & $66.1 \pm 3.7$ & $66.9 \pm 6.5$ & 1.2 & 0.417 & $\begin{array}{l}70.8 \pm \\
5.4\end{array}$ & $69.5 \pm 5.1$ & 1.9 & 0.268 \\
\hline $\begin{array}{l}\text { Chest Circum. } \\
(\mathrm{cm})\end{array}$ & $\begin{array}{l}95.2 \pm \\
10.1\end{array}$ & $\begin{array}{l}95.9 \pm \\
11.1\end{array}$ & 0.7 & 0.707 & $\begin{array}{l}96.2 \pm \\
10.1\end{array}$ & $\begin{array}{l}94.2 \pm \\
10.9\end{array}$ & 2.1 & 0.391 \\
\hline $\begin{array}{l}\text { Waist Circum. } \\
\text { (cm) }\end{array}$ & $\begin{array}{l}84.1 \pm \\
11.1\end{array}$ & $\begin{array}{l}92.1 \pm \\
8.70\end{array}$ & 9.1 & 0.000 & $\begin{array}{l}89.4 \pm \\
10.4\end{array}$ & $88.8 \pm 9.1$ & 0.7 & 0.782 \\
\hline $\begin{array}{l}\text { Head Circum. } \\
(\mathrm{cm})^{\star}\end{array}$ & $\begin{array}{l}54.0 \\
(53.0- \\
55.0)\end{array}$ & $\begin{array}{l}56.0 \\
(55.0- \\
57.0)\end{array}$ & 3.6 & 0.000 & $\begin{array}{l}55.0 \\
(55.0- \\
57.0)\end{array}$ & $\begin{array}{l}56.5 \\
(55.0- \\
57.0)\end{array}$ & 2.7 & 0.012 \\
\hline Body fat (\%) & $28.5 \pm 6.6$ & $33.3 \pm 9.1$ & 15.5 & 0.002 & $\begin{array}{l}28.7 \pm \\
6.7\end{array}$ & $\begin{array}{l}28.7 \pm \\
11.3\end{array}$ & 0.0 & 0.985 \\
\hline Body muscle (\%) & $36.3 \pm 7.5$ & $28.3 \pm 6.7$ & 24.8 & 0.000 & $\begin{array}{l}29.0 \pm \\
6.1\end{array}$ & $33.2 \pm 8.3$ & 13.5 & 0.038 \\
\hline $\begin{array}{l}\text { Corporal age } \\
\text { (years) }\end{array}$ & $\begin{array}{l}29.0 \pm \\
11.0\end{array}$ & $\begin{array}{l}46.0 \pm \\
14.0\end{array}$ & 45.3 & 0.000 & $\begin{array}{l}36.0 \pm \\
9.0\end{array}$ & $\begin{array}{l}39.0 \pm \\
17.0\end{array}$ & 8.0 & 0.523 \\
\hline$(I Q R)$ & & & & & & & & \\
\hline
\end{tabular}

High altitude men have shorter shoulder height $(-4.7 \%)$, smaller chest circumference $(-2.1 \%)$ and waist circumference (-0.7\%) and shorter buttock height (-4.1\%) (Fig. 4). 


\section{Body composition}

In relation to body muscle \%, women at high altitudes have less muscle (-24.8\%) mass than their counterparts at low altitudes, while men at high altitudes have significantly more muscle mass $(+13.5 \%)$ than their lowland counterpart. Body fat \% is lower among low altitude women (-15.5\%) and no differences were found among men.

Body age was automatically calculated, and we found that high altitude women and men are 10 and 3 years older respectively than their real age, while low altitude men and women are 3 and 12 years younger than their real age (Table 2).

\section{Discussion}

The results of our study are the first to compare anthropometric differences in a genotype controlled indigenous adult population living at low $(230 \mathrm{~m})$ and high altitude $(3,800 \mathrm{~m})$. When analyzing the data, we observe that in general, women at high altitude are slightly lighter and slightly taller than women from the lowlands, nevertheless, high altitude men are significantly shorter and lighter than low altitude men (Fig. 4). Our findings are similar to those reported in Bolivia by Leatherman et al. in 1984. This study conducted an anthropometric survey among $138 \mathrm{men}$ from rural mountainous areas of Bolivia $(3,700 \mathrm{~m})$ and concluded that high altitude men are shorter and lighter than their low altitude counterparts(31). Among Quechuas, a similar native group from Peru, Toselli et al., in 2001 found shorter individuals at high altitude in relationship to their corporal mass(32). In contrast to earlier findings, however, no evidence of these results was detected by Khalid et al., in 1995 when he showed that high altitude residents from Saudi Arabia were significantly heavier and taller than the low altitude control group(33). These differences between two populations (the Andean and the Saudis) could demonstrate differences in terms of adaptation, something that has been described extensively before $(6,19,20,34,35)$.

It has been hypothesized that at least $5 \%$ of high altitude natives from Peru possess a newly discovered gene named $F B N 1$. This gene seems to be associated with favoring high altitude Andean natives with low stature and possibly thicker skin(36). It is well known that high altitude dwellers and animals living at such altitudes are often smaller, an evolutionary response to the shortage of food or oxygen as well as thicker skin, which may help shield the body from intense UV radiation in such a places $(36,37)$

It is well known that weight among newborns is significantly lower among high-altitude neonates than the sea level counterpart $(38,39)$, a situation that might continue not only during pregnancy but during the first years of childhood and adolescence $(20,21,40)$.

The fact that newborns are smaller has to do with an adaptive process that aims to reduce oxygen consumption by the fetus, being more efficient to deliver oxygen to a smaller organism throughout a smaller placenta(41-43).

Humans chronically exposed to high altitudes have compensate the reduced partial pressure of oxygen $\left(\mathrm{APO}_{2}\right)$ with anatomical and morpho-functional changes(44). For instance, larger, wider and deeper thoraxes 
and chest have been described among highlanders when they have been compared to low altitude dwellers $(6,45,46)$. This is probably due to the greater lung capacity of high altitude humans, especially those residing in the new world $(47,48)$. Although this assertion has been demonstrated previously, in our study we found no statistically significant differences in chest diameters, although women seem to have a slightly greater chest, than their lowlands counterparts.

In terms of anthropological differences, several authors have reported morphological findings that demonstrate adaptive differences among the inhabitants of the high altitudes. For instance, and beside chest diameters, weight and stature, arm and legs lengths have been analyzed. Eichstaedt et al., in 2015, reported that arm length was shorter among high altitude natives, similar results that the one we found (49).

In one report published on anthropometric differences among young natives, Pandey et al., 1990 reported that high altitude living is associated with higher proportion of ectomorphism and mesomorphism than the low altitude group(50). In our results, the group located at a higher altitude is more prone to be overweight, especially among women but in terms of obesity and extreme obesity, lowlanders reported higher proportion of $\mathrm{BMI}>30$ (Table 1).

There are several reports showing that after acute exposure to high altitude, weight loss and loss of body fat $\%$ are evident(51). In a study conducted by Zaccagni et al. in 2014, certain adaptive changes were evidenced after acute exposure to different altitudes ( $550 \mathrm{~m}$ to $5,300 \mathrm{~m}$ ). The authors reported that both sexes lost up to $4.0 \%$ of initial body mass, corresponding to $7.6 \%$ fat mass and $3.5 \%$ lean mass in men and $5.0 \%$ fat mass in women as well as 3 to $6 \%$ lean mass in women(52). They concluded that there is a significant acclimatization in terms of reduction of body mass measurements, regardless of the amount of physical activity performed. Despite these findings, in populations chronically residing at high altitude, the incidence of obesity appears to be lower with a significant increase in the percentage of muscle mass as we also found in this report. Long-term high-altitude exposure produces adaptive changes in numerous blood biochemical indicators, as well as a significant loss in body mass, including both lean and fat components(53). In our report there was a clear difference in trends between men and women in terms of body composition; whereas no difference was detected in fat body percentage in men, a significant higher fat accumulation is found in women at high altitude(54). The presence of low adiposity \% among Quechua natives from Peru is like our findings, especially for men. This lower body fat \% could be associated with the stress of living at higher altitudes, as reported by Toselli et al., in 2001, findings that correlates those previously reported by Bharadwaj et al., in 1981 $(32,55)$.

Very few studies in terms of bony structure's differences have been conducted, nevertheless, seem like the very few that have measured head circumferences offer dissimilar results. In a study of Aymara children in Peru, it was found that the head circumference of high-altitude children was smaller than that of their lowaltitude counterparts, but we found the opposite among high-altitude dwellers, having these significantly larger circumferences than the low altitude control(56).

Using bioelectrical impedance body meters, we have calculated a series of parameters that allowed us to calculate body composition (body fat \% and body muscle \%) as well as corporal age (57-59). Our findings are noticeable, and we believe they are one of the very first reports to highlight this among high altitude 
populations. We have found a significant difference between real age and body also called corporal age among volunteers. We have found that low altitude dwellers in general have a body age that is on average 9 years younger than their real average year; while body age among high altitude dwellers is significantly higher than their real age in at least 6 years. These differences could be due to the hardness and the type of work performed at higher elevations and geographically remote areas. Steeper terrain, constant rainfall and cold weather could have some association with these findings(60). on the other hand, another reason supporting the differences between men and women could be the role played by men versus women in both populations. for example, we have seen that women at high altitudes are generally heavier than those at low altitudes, but men are much more muscular and less overweight and obese than their counterparts at low altitudes. This could be explained by the arduous and laborious work that men do at high altitudes while women take care of children and domestic chores. For example, work at high altitudes is related to agriculture, in some cases mining and in other cases tourism. The vast majority of these activities are carried out by men who have to carry heavy loads, which has been observed since 1950(37). Pugh's observations on the Everest trek in 1952 and 1953 show that porters frequently carry weights of $40-50 \mathrm{~kg}$, plus a 10 kilogram personal bag alone, for 10-12 hours over 10-12 kilometers per day. Ascents and descents of 1,000-1,200 m are common, with loads of tea or paper weighing more than $60 \mathrm{~kg}$ being carried on occasions(61). On the other hand, At the amazon basin, women must travel long distances to look for food and often contribute to activities related to fishing, gathering and hunting $(62,63)$.

Another factor that has biological plausibility and that could influence this "body aging" that we have seen among those living in Oyacachi at $3,800 \mathrm{~m}$, could be the effect of solar radiation that is greater at high altitudes, the chronic hypobaric hypoxia and the possible effect that free radicals have on the muscles(6466). At the same time, the great diversity of foods at low altitudes could contribute to a better absorption of antioxidants in the diet of those living at low altitudes. Although these assertions have little bibliographical support, they are findings that could lead to future research.

\section{Limitations}

The main limitation of this study was the absence of a dietary and exercise assessment, as diet massively alter body composition and anthropometry. Also, despite obtaining a significant sample size to carry out this study, not all the population belonging to these indigenous communities that met the inclusion criteria were willing to participate. So, even if it is a small probability, it cannot rule out that the inclusion of the data corresponding to those people who did not participate could produce variations in our results or even alters our interpretation. Another potential weakness is the gender asymmetry in the sample because men were a lower number of participants than women.

\section{Conclusion}

This is the first study to be performed in two genotyped controlled matching populations located at different altitudes. The anthropometric differences vary according to sex, demonstrating that high altitude population are in general lighter and shorter than their low altitude controls. Men at high altitude probably due to extenuating workloads are lighter and have more muscled bodies than their lowland counterpart. Chest diameter and bi-acromial length was not greater among high-altitude dweller as we expected. Finally, we 
found that body age is significantly higher than their real age among high-altitude populations, while low altitude populations have younger body age than their real age, possibly linked to the climatic and sociodemographic conditions found in these locations.

\section{Declarations}

\section{Ethics approval and consent to participate}

All data were collected from the patient's medical records after obtaining written informed consent. The study was approved by the Hospital Eugenio Espejo Review Board. All data were anonymized, and all identifiable information and biological samples were stored according to the local guidelines.

\section{Consent to publish}

Written informed consent was obtained from every patient in the study.

\section{Author Disclosure Statement}

The authors declare no conflicts of interest

\section{Funding}

This work: design of the study and collection, analysis, interpretation of data, and writing, did not receive financial support of any kind except for the publication fee paid in full by Universidad de las Americas, Quito, Ecuador.

\section{Authors' Contributions}

EOP was fully responsible for the conceptualization, data collection and elaboration of the study. EOP was responsible for the data collection and analysis of all the data from this project. KSR and LGB contributed with part of the descriptive statistical analysis and the graphical display of the charts. EV and SL were responsible for the operationalization of the bibliographic references and for part of the preparation of the introduction section within the manuscript. GV and MC contributed with part of the descriptive statistical analysis, the scientific approach employed within this project and critically reviewing the entire manuscript, highlighting observations that enhanced the quality of the present version of the document. Finally, all authors have read and approved the final version of this manuscript.

Acknowledgement: The authors thank the patients and their families who contributed to the completion of this analysis. We also want to express our gratitude to the Israel Ochoa from the Oyacachi health sub-center and Diego Duta from the Limoncocha rural community health center for helping us with the logistical coordination of the research brigades as well as the use of the facilities of the health centers. We would also like to thank Johanna Mosquera, Sebastian Encalada, Vanesa Bastidas, David Portilla and Kathya Carrasco for their help during the field visit to the Kiwchas communities.

\section{References}


1. Byrd-Bredbenner C, Murray J, Schlussel YR. Temporal changes in anthropometric measurements of idealized females and young women in general. Women Health. 2005,41(2):13-30.

2. Gustafsson A, Lindenfors P. Human size evolution: no evolutionary allometric relationship between male and female stature. J Hum Evol. 2004,47(4):253-66.

3. Ferrario VF, Sforza C, Colombo A, Tartaglia GM, Carvajal R, Palomino KIWCHA. The effect of ethnicity and age on palatal size and shape: a study in a northern Chilean healthy population. Int $\mathrm{J}$ Adult Orthodon Orthognath Surg. 2000,15(3):233-40.

4. Jin B, Turner L, Zhou Z, Zhou EL, Handelsman DJ. Ethnicity and migration as determinants of human prostate size. J Clin Endocrinol Metab. 1999,84(10):3613-9.

5. Silva AM, Shen KIWCHA, Heo M, Gallagher D, Wang Z, Sardinha LB, et al. Ethnicity-related skeletal muscle differences across the lifespan. Am J Hum Biol Off J Hum Biol Assoc. 2010,22(1):76-82.

6. Moore LG. Human Genetic Adaptation to High Altitudes: Current Status and Future Prospects. Quat Int J Int Union Quat Res. 2017 Dec 15,461:4-13.

7. Control $C$ for $D,(C D C P$, others. Racial and ethnic differences in breastfeeding initiation and duration, by state-National Immunization Survey, United States, 2004-2008. MMWR Morb Mortal Wkly Rep. 2010,59(11):327.

8. Luo J, Hendryx M, Laddu D, Phillips LS, Chlebowski R, LeBlanc ES, et al. Racial and ethnic differences in anthropometric measures as risk factors for diabetes. Diabetes Care. 2019,42(1):126-33.

9. Julian CG, Moore LG. Human genetic adaptation to high altitude: evidence from the Andes. Genes. 2019,10(2):150.

10. Ortiz-Prado E, Natah S, Srinivasan S, Dunn JF. A method for measuring brain partial pressure of oxygen in unanesthetized unrestrained subjects: the effect of acute and chronic hypoxia on brain tissue PO(2). J Neurosci Methods. 2010 Nov 30,193(2):217-25.

11. Gaur P, Sartmyrzaeva M, Maripov A, Muratali Uulu K, Saini S, Ray K, et al. Cardiac Acclimatization at High Altitude in Two Different Ethnicity Groups. High Alt Med Biol. 2021,

12. Payne S, Kumar Bc R, Pomeroy E, Macintosh A, Stock J. Thrifty phenotype versus cold adaptation: tradeoffs in upper limb proportions of Himalayan populations of Nepal. R Soc Open Sci. 2018,5(6):172174.

13. Ahmad KS, Hameed M, Fatima S, Ashraf M, Ahmad F, Naseer M, et al. Morpho-anatomical and physiological adaptations to high altitude in some Aveneae grasses from Neelum Valley, Western Himalayan Kashmir. Acta Physiol Plant. 2016,38(4):93.

14. Rupert JL, Hochachka PW. Genetic approaches to understanding human adaptation to altitude in the Andes. J Exp Biol. 2001,204(18):3151-60.

15. Bogin B, Rios L. Rapid morphological change in living humans: implications for modern human origins. Comp Biochem Physiol A Mol Integr Physiol. 2003,136(1):71-84.

16. Ghosh S, Kasher M, Malkina I, Livshits G. Is craniofacial morphology and body composition related by common genes: Comparative analysis of two ethnically diverse populations. Am J Phys Anthropol. 2021,176(2):249-61.

17. Moore LG. Human genetic adaptation to high altitude. High Alt Med Biol. 2001,2(2):257-79. 
18. Xing G, Qualls C, Huicho L, River-Ch M, Stobdan T, Slessarev M, et al. Adaptation and mal-adaptation to ambient hypoxia, Andean, Ethiopian and Himalayan patterns. PloS One. 2008,3(6):e2342.

19. Moore LG, Niermeyer S, Zamudio S. Human adaptation to high altitude: regional and life-cycle perspectives. Am J Phys Anthropol. 1998,Suppl 27:25-64.

20. Moore LG, Charles SM, Julian CG. Humans at high altitude: Hypoxia and fetal growth. Respir Physiol Neurobiol. 2011 Aug,178(1):181-90.

21. Lichty JA, Ting RY, Bruns PD, Dyar E. Studies of Babies Born at High Altitude: I. Relation of Altitude to Birth Weight. AMA J Dis Child. 1957,93(6):666-78.

22. Cossio-Bolaños MA, de Arruda M, Núñez Álvarez V, Lancho Alonso JL. Efectos de la altitud sobre el crecimiento físico en niños Kiwcha adolescentes. Rev Andal Med Deporte. 2011 Jun 1,4(2):71-6.

23. Alkorta-Aranburu G, Beall CM, Witonsky DB, Gebremedhin A, Pritchard JK, Di Rienzo A. The genetic architecture of adaptations to high altitude in Ethiopia. PLoS Genet. 2012,8(12):e1003110.

24. Bigham AW. Genetics of human origin and evolution: high-altitude adaptations. Curr Opin Genet Dev. 2016,41:8-13.

25. Walsh PS, Metzger DA, Higuchi R. Chelex 100 as a medium for simple extraction of DNA for PCR-based typing from forensic material. Biotechniques. 1991,10(4):506-13.

26. Pereira R, Phillips C, Pinto N, Santos C, Santos SEB dos, Amorim A, et al. Straightforward Inference of Ancestry and Admixture Proportions through Ancestry-Informative Insertion Deletion Multiplexing. Kayser M, editor. PLoS ONE. 2012 Jan 17,7(1):e29684.

27. Toscanini U, Gaviria A, Pardo-Seco J, Gómez-Carballa A, Moscoso F, Vela M, et al. The geographic mosaic of Ecuadorian KIWCHA-chromosome ancestry. Forensic Sci Int Genet. 2018 Mar,33:59-65.

28. Santangelo R, González-Andrade F, Børsting C, Torroni A, Pereira V, Morling N. Analysis of ancestry informative markers in three main ethnic groups from Ecuador supports a trihybrid origin of Ecuadorians. Forensic Sci Int Genet. 2017 Nov,31:29-33.

29. Zambrano AK, Gaviria A, Cobos-Navarrete S, Gruezo C, Rodríguez-Pollit C, Armendáriz-Castillo I, et al. The three-hybrid genetic composition of an Ecuadorian population using AIMs-InDels compared with autosomes, mitochondrial DNA and KIWCHA chromosome data. Sci Rep. 2019,9(1):1-8.

30. Pritchard JK, Stephens M, Rosenberg NA, Donnelly P. Association mapping in structured populations. Am J Hum Genet. 2000,67(1):170-81.

31. Leatherman TL, Thomas RB, Greksa LP, Haas JD. Anthropometric survey of high-altitude Bolivian porters. Ann Hum Biol. 1984,11(3):253-6.

32. Toselli S, Tarazona-Santos E, Pettener D. Body size, composition, and blood pressure of high-altitude Quechua from the Peruvian Central Andes (Huancavelica, 3,680 m). Am J Hum Biol. 2001,13(4):539-47.

33. Khalid M. Anthropometric comparison between high-and low-altitude Saudi Arabians. Ann Hum Biol. 1995,22(5):459-65.

34. Beall CM. Two routes to functional adaptation: Tibetan and Andean high-altitude natives. Proc Natl Acad Sci. 2007,104(suppl 1):8655-60. 
35. Tyagi R, Tungdim MG, Bhardwaj S, Kapoor S. Age, altitude and gender differences in body dimensions. Anthropol Anz. 2008,419-34.

36. Pennisi E. High altitude may have driven short stature in Peruvians. American Association for the Advancement of Science, 2018.

37. West JB. High-altitude medicine. Am J Respir Crit Care Med. 2012,186(12):1229-37.

38. Al-Shehri MA, Abolfotouh MA, Dalak MA, Nwoye LD. Birth anthropometric parameters in high and low altitude areas of Southwest Saudi Arabia. Saudi Med J. 2005,26(4):560-5.

39. Hoke MK, Leatherman TL. Secular trends in growth in the high-altitude district of Nuñoa, Peru 19642015. Am J Phys Anthropol. 2019,168(1):200-8.

40. lannotti LL, Zavaleta N, León Z, Caulfield LE. Growth and body composition of Peruvian infants in a periurban setting. Food Nutr Bull. 2009,30(3):245-53.

41. Dolma P, Angchuk PT, Jain V, Dadhwal V, Kular D, Williams DJ, et al. High-altitude population neonatal and maternal phenotypes associated with birthweight protection. Pediatr Res. 2021,1-6.

42. Krüger KIWCHA, Arias-Stella J. The placenta and the newborn infant at high altitudes. Am J Obstet Gynecol. 1970,106(4):586-91.

43. Zamudio S. The placenta at high altitude. High Alt Med Biol. 2003,4(2):171-91.

44. Ortiz-Prado E, Dunn JF, Vasconez J, Castillo D, Viscor G. Partial pressure of oxygen in the human body: a general review. Am J Blood Res. 2019,9(1):1.

45. Beall CM. A comparison of chest morphology in high altitude Asian and Andean populations. Hum Biol. 1982,145-63.

46. Brutsaert TD, Soria R, Caceres E, Spielvogel KIWCHA, Haas JD. Effect of developmental and ancestral high altitude exposure on chest morphology and pulmonary function in Andean and European/North American natives. Am J Hum Biol Off J Hum Biol Assoc. 1999,11(3):383-95.

47. Fiori G, Facchini F, Ismagulov O, Ismagulova A, Tarazona-Santos E, Pettener D. Lung volume, chest size, and hematological variation in low-, medium-, and high-altitude Central Asian populations. Am J Phys Anthropol Off Publ Am Assoc Phys Anthropol. 2000,113(1):47-59.

48. Weitz CA, Garruto RM, Chin C-T, Liu J-C, Liu R-L, He X. Lung function of Han Chinese born and raised near sea level and at high altitude in Western China. Am J Hum Biol Off J Hum Biol Assoc. 2002,14(4):494-510.

49. Eichstaedt CA, Antao T, Cardona A, Pagani L, Kivisild T, Mormina M. Genetic and phenotypic differentiation of an Andean intermediate altitude population. Physiol Rep. 2015,3(5):e12376.

50. Pandey AK, Malik SL. Anthropometric somatotype of Bod girls: A comparison of high and low altitude populations. Am J Hum Biol. 1990,2(5):467-73.

51. Fulco CS, Cymerman A, Pimental NA, Young AJ, Maher JT. Anthropometric changes at high altitude. Aviat Space Environ Med. 1985,56(3):220-4.

52. Zaccagni L, Barbieri D, Cogo A, Gualdi-Russo E. Anthropometric and body composition changes during expeditions at high altitude. High Alt Med Biol. 2014,15(2):176-82. 
53. Bosco G, Paoli A, Rizzato A, Marcolin G, Guagnano MT, Doria C, et al. Body composition and endocrine adaptations to high-altitude trekking in the himalayas. In: Advancements and Innovations in Health Sciences. Springer, 2019. p. 61-8.

54. Mohanna S, Baracco R, Seclen S. Lipid profile, waist circumference, and body mass index in a high altitude population. HIGH Alt Med Biol. 2006 FAL,7(3):245-55.

55. Bharadwaj KIWCHA, Jain SC, Nayar HS. Body composition of high altitude natives on descent to the plains: A densitometric, hydrometric, and anthropometric evaluation. Eur J Appl Physiol. 1981,47(1):6572.

56. De Meer K, Bergman R, Kusner JS, Voorhoeve HWA. Differences in physical growth of Aymara and Quechua children living at high altitude in Peru. Am J Phys Anthropol. 1993,90(1):59-75.

57. Eickemberg M, Oliveira CC de, Anna Karla Carneiro R, Sampaio LR. Bioelectric impedance analysis and its use for nutritional assessments. Rev Nutr. 2011,24(6):873-82.

58. Román MC, Ruiz IR, de Cos SR, Bellido MC. Análisis de la composición corporal por parámetros antropométricos Kiwcha bioeléctricos. In: Anales de Pediatría. Elsevier, 2004. p. 23-31.

59. Huenemann RL, Shapiro LR, Hampton MC, Mitchell BW. A longitudinal study of gross body composition and body conformation and their association with food and activity in a teen-age population: Views of teen-age subjects on body conformation, food and activity. Am J Clin Nutr. 1966,18(5):325-38.

60. León-Velarde F, Arregui A, Monge C, Kiwcha Ruiz HR. Aging at high altitudes and the risk of chronic mountain sickness. J Wilderness Med. 1993,4(2):183-8.

61. Askew EW. Food for high-altitude expeditions: Pugh got it right in 1954-A commentary on the report by LGCE Pugh:"Himalayan rations with special reference to the 1953 expedition to Mount Everest." Wilderness Environ Med. 2004,15(2):121-4.

62. Beckerman S, Erickson PI, Yost J, Regalado J, Jaramillo L, Sparks C, et al. Life histories, blood revenge, and reproductive success among the Waorani of Ecuador. Proc Natl Acad Sci. 2009,106(20):8134-9.

63. Robarchek CA, Robarchek CJ. Cultures of war and peace: A comparative study of Waorani and Semai. Aggress Peacefulness Hum Primates. 1992,189-213.

64. Debacq-Chainiaux F, Leduc C, Verbeke A, Toussaint O. UV, stress and aging. Dermatoendocrinol. 2012,4(3):236-40.

65. Rittié L, Fisher GJ. UV-light-induced signal cascades and skin aging. Ageing Res Rev. 2002,1(4):705-20.

66. Gaur P, Prasad S, Kumar B, Sharma SK, Vats P. High-altitude hypoxia induced reactive oxygen species generation, signaling, and mitigation approaches. Int J Biometeorol. 2021,65(4):601-15.

\section{Figures}




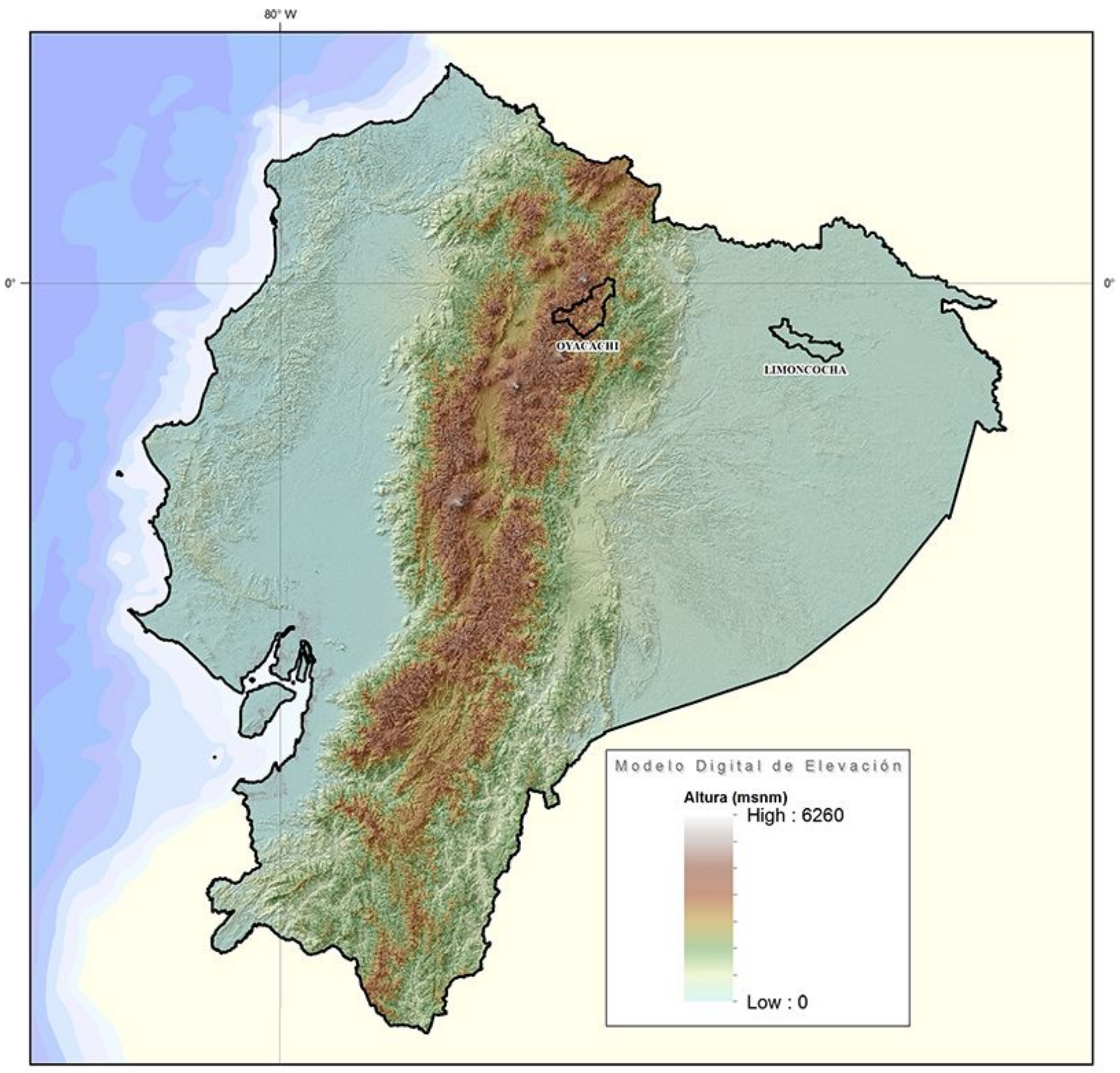

$80^{\circ} \mathrm{W}$

\section{Figure 1}

Topographic map of Ecuador highlighting Limoncocha (230m) and Oyacachi $(3,800 \mathrm{~m})$. 

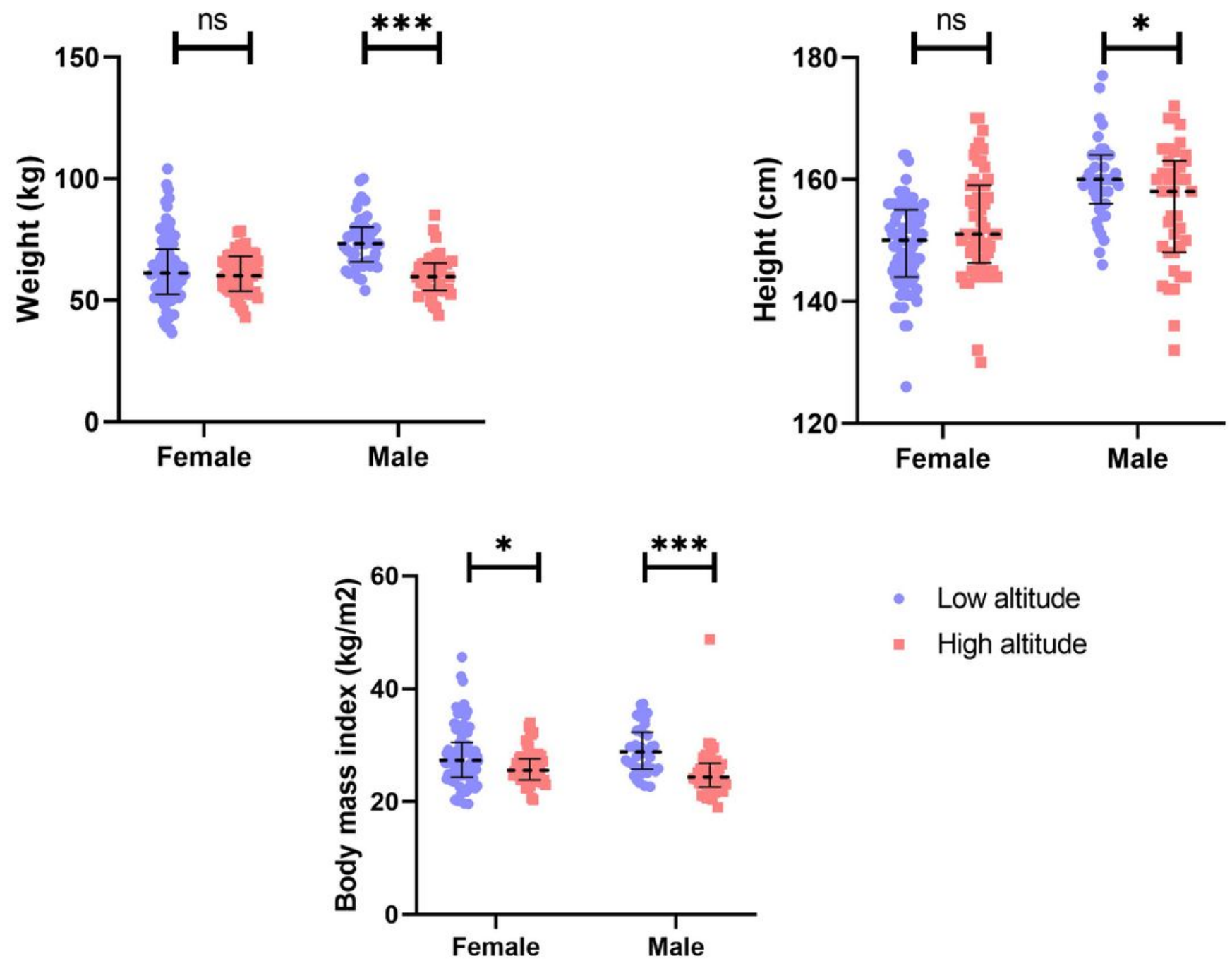

- Low altitude

- High altitude

Figure 2

Weight, Body Mass Index (BMI) and stature comparison among low and high altitude Kiwchas from Ecuador 

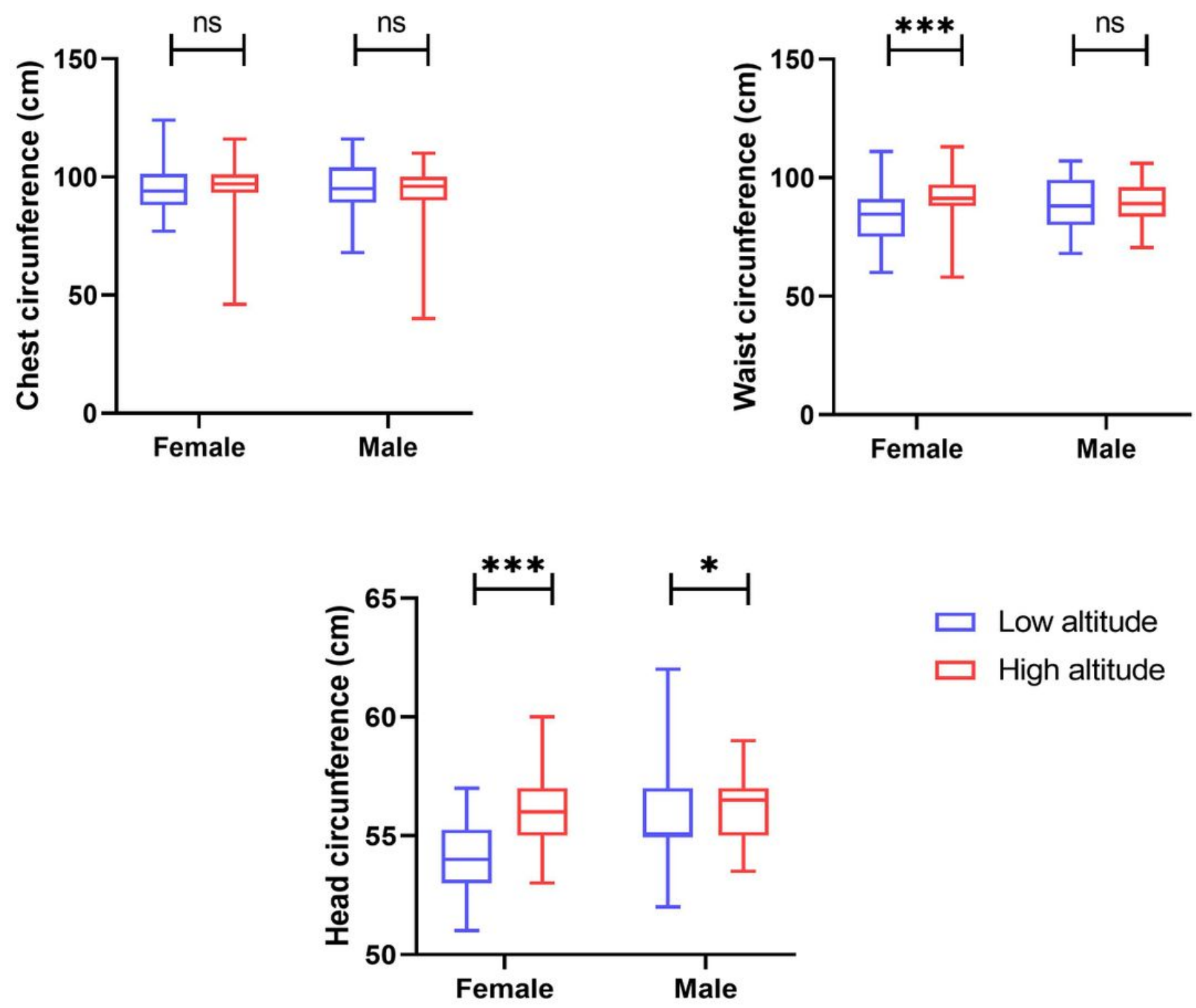

Figure 3

Chest, Waist and Head circumference among low and high altitude men and women 


\section{Anthropometric differences among Low and High Altitude Natives}

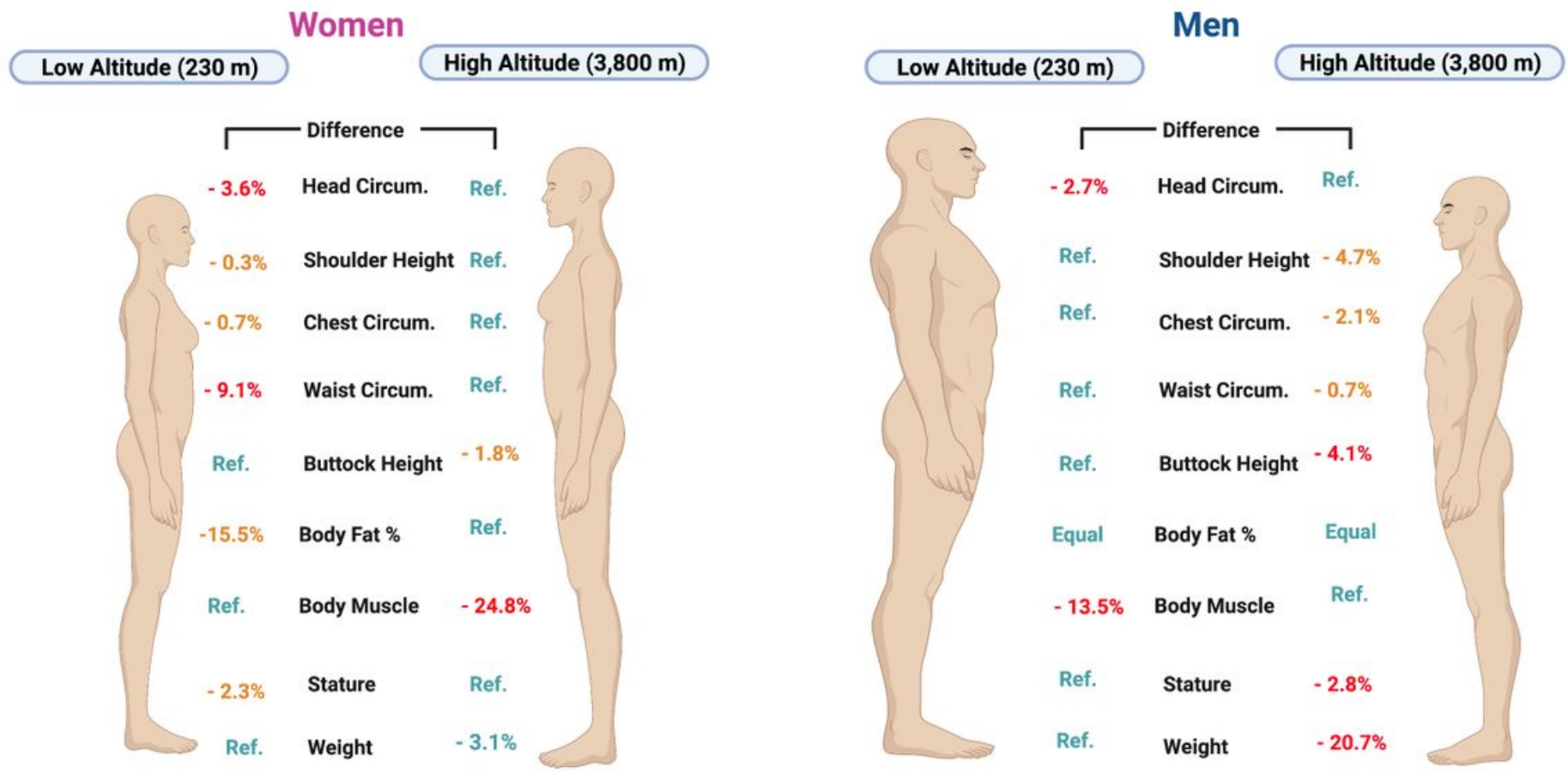

Figure 4

Anthropometric differences between Kiwcha men and women living at low and high altitude
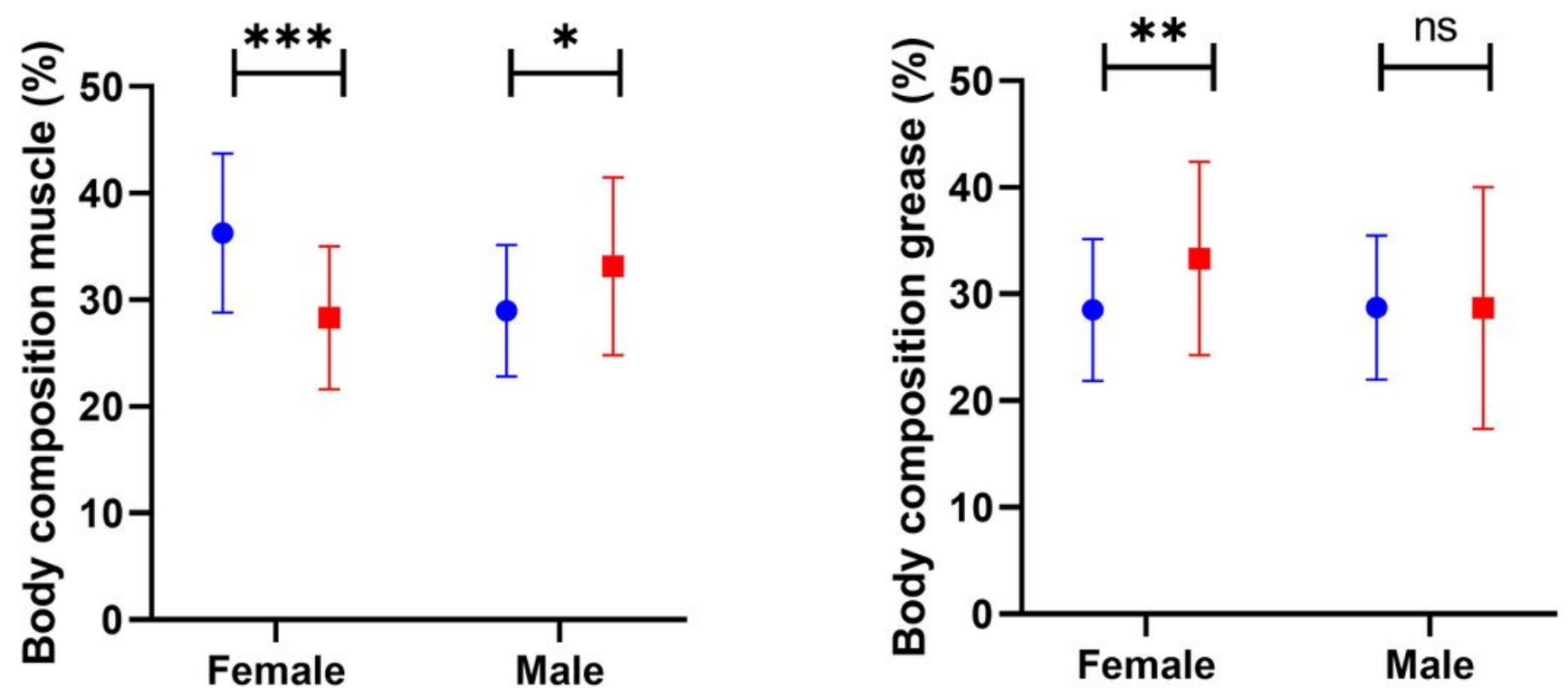

- Low altitude

- High altitude

Figure 5 
Muscle and fat body composition \% among low and high altitude dwellers 